\title{
The Magellan-Antarctic connection: links and frontiers at southern high latitudes. Summary review
}

\author{
WOLF E. ARNTZ \\ Alfred-Wegener-Institut für Polar- und Meeresforschung, Bremerhaven, Germany.
}

Eight years of research in the Magellan region and Antarctic marine ecosystems have passed since the first IBMANT Symposium held in Punta Arenas in 1997 (Arntz and Ríos, 1999). Considerable biogeographic and biodiversity work, supported by physiological and molecular genetic approaches, has been published during this time, especially in the Antarctic, much of it in the framework of SCAR's EASIZ and EVOLANTA programmes (Di Prisco et al., 1998; Davison et al., 2000; Arntz and Clarke, 2002; Huiskes et al., 2003; Clarke et al., subm.), and recently by research extending into the deep sea (Brandt and Hilbig, 2004). Marine science in the Magellan region, which had received important stimuli from the "Victor Hensen" and "Vidal Gormaz" campaigns in the previous period (Arntz and Gorny, 1996; CONA, 1999 a, b), was advanced rather by individual approaches such as the decapod and fish work carried out by the CADIC and colleagues from Ushuaia (e.g. Lovrich et al., 2003; Fernández et al., 2000) but also received further input from CIMAR Fiordo cruises nos. 3, 4, and 7 between 1997 and 2001, and the "LAMPOS" cruise of RV "Polarstern" along the Scotia Arc (CONA, 1999 a, b; Arntz and Brey, 2003).

Despite all these efforts, and a wealth of information presented and discussed during the Ushuaia IBMANT II Symposium, it is obvious that important gaps remain and a number of basic questions may not be solved in the immediate future (see Editorial to this volume). Among these are issues to be solved by geologists, palaeontologists and oceanographers, such as the exact timing of the final ocean gateway opening and the onset of a vigorous circum-Antarctic current system (Barker and Burrell, 1977; Barker and Thomas, 2004; Mackensen, 2004; Thomson*). Furthermore, the use of molecular approaches for the timing of biogeographic, radiation and extinction events has by no means been further advanced: depending on the method applied the results may differ by several million years (Hillis et $a l .$, 1996). Thus, while it is hard to imagine how we can reach, at least in the short term, the intended close correlation between revolutionary changes in the polar environment and important biological processes, the only possible way out is close cooperation between disciplines, as is intended for the upcoming International Polar Year.

In the following an attempt is made to briefly summarise some of the results presented in this second IBMANT volume. They contribute to, and to some extent complement, the major issues and questions presented in the Foreword, and may therefore be seen as an updating of knowledge on biological interactions between the Magellan region and the Antarctic.

A traditional view is to see the Antarctic as an ecosystem that is almost perfectly isolated by deep 
sea, circular currents and powerful fronts between water bodies of different properties. But how hermetic are these fronts? Mesoscale eddies are a dominant feature of circulation and play a fundamental role in the transport of water along and across the Antarctic Circumpolar Current (ACC; Glorioso et al.). Cross-frontal eddy transport and meandering have been encountered in particular along the Subantarctic Front and the southern ACC Front. These results are of utmost importance in the present situation of a warming planet, in which small increases in Southern Ocean water temperature may result in increased settling success of alien meroplanktonic larvae south of the Polar Front (Thatje and Fuentes, 2003), where the benthic biota may not have developed defence mechanisms.

Diversity and distribution of zooplankton, compared to the benthos, are much less affected by the Polar Front, although the cold-water convergence of the Polar Front is more important than the front between the tropics and subtropics. Worldwide, species richness of benthos is several degrees of magnitude higher than that of plankton, whose ecological relevance is not paralleled by its diversity. However, zooplankton species in the Atlantic sector of the Southern Ocean contribute an important share to the world-wide inventory of this group, which is almost twice as high as that of benthos. On the other hand, benthic endemism in these cold waters is much higher than that of plankton. Detachment from the bottom apparently results in wider geographic ranges and lower degrees of endemism (Boltovskoy et al.).

A first study of mesozooplankton was carried out in the northern Beagle Channel near Ushuaia (Fernández and Hoffmeyer). Copepods were the dominant taxon. Most of the species found are typical of the Subantarctic, but some common species are present in high numbers also at Antarctic coastal sites, confirming that the Polar Front is probably not a major geographic barrier for the distribution of pelagic species.

Pelagobenthic coupling has been well studied in the Antarctic but sadly little is known from the Magellan region. The marked spring-summer peak of particle fluxes in the Antarctic water column and at shallower depths is concealed at the deeper seabeds due to suspension and lateral advection. Faecal pellets of various origins are the main constituents of the biogenic matter flux, but the role of distinct taxa requires further study. Aggregation of particles favours the transfer of high-quality organic matter to the benthos. Both faecal pellets and aggregates reduce the residence time of biogenic matter in the water column and favour the accumulation of highly nutritive material on the seafloor. The suspected poor species number and abundance of meroplanktonic larvae needs further confirmation (SchnackSchiel and Isla).

The Patagonia-high Weddell Sea gradient is not the only latitudinal gradient presently under study. Marine research is also being undertaken along Victoria Land (Ross Sea) between 72 and $86^{\circ} \mathrm{S}$ by a consortium of Italian, New Zealand and U.S. scientists (Berkman $\boldsymbol{e t}$ al. .). The preliminary results show that this area will yield highly interesting comparisons with results obtained in the Weddell Sea, including an extension to even higher latitudes. As only part of the Victoria Land gradient has an ice shelf coast, one important research issue might be to find out to what extent ice shelves influence the composition of the "circum-Antarctic" fauna and flora; e.g. missing macroalgae and rare occurrence of scallops in the Weddell Sea vs. abundant populations in the Ross Sea.

The Scotia Arc is the only shallow-water and island bridge linking the Antarctic nowadays with the surrounding continents. It has now amongst the fastest rates of environmental change measured. Shallow-water benthos was studied by Barnes in the context of this change. Due to the long dark winter, benthic life is mostly in the slow lane. During summer, shallow communities are intensely disturbed by ice scour and wave action, resulting in a lack of shore zonation and low species richness contrary to the conditions in the subtidal. As in deeper water (see Arntz et al.) there is no consistent latitudinal cline in species richness, rather a dependency on the degree of isolation of various sites, and some taxa are much more speciose than in southern hemisphere temperate waters. The islands of the Arc might serve as stepping stones for those faunal and floral elements which have dispersal capabilities to bridge short deep-sea distances. Eastward transport with the ACC is much more likely than the return in westerly direction, but the Weddell Sea Eddy, the East Wind Drift, and transport across the Polar Front by eddies originating from the valve effect of the Drake Passage (Glorioso et al.) might also contribute to exchange processes, which under the present fast rates of climate change might result in successful colonisation by "aliens".

Another shallow-water study (to $40 \mathrm{~m}$ depth) deals with the distribution of actinians along the 
Chilean coast (Häussermann and Försterra). A total of 32 species of Actiniaria and Corallimorpharia were found, 23 of which occurred in the wellstructured southern fjord system. A comparison based on extensive literature is made with data from Argentina (18 overlapping spp. of a total of 70) and the Antarctic (13 overlapping species). Many literature records need revision or confirmation.

Studying the 78 bryozoan species collected during the LAMPOS cruise, Moyano distinguished the island groups east and south of Shag Rocks as Antarctic, whereas Burdwood Bank clustered with Tierra del Fuego. Considering all records hitherto (214 spp.), the Antarctic Peninsula clustered with the Scotia Arc, whereas a second cluster comprised the Magellan region and the Falklands. Using bryozoan material (genera) from Australia and New Zealand, these areas join the Magellan region.

From bivalve material (74 spp.) sampled during the same expedition along the Scotia Arc, Zelaya noticed a higher similarity with the Weddell Sea (50-85\% overlap) than with Patagonia and the Falkland (Malvinas) Islands (12-29\%). The high Antarctic Weddell Sea and Patagonia/Falklands only shared $10 \%$ of their species. Bivalves from South Georgia were predominantly Antarctic. Bivalve distribution supports the placement of the Scotia Arc islands within the Antarctic region.

The species number of polychaetes in the south Chilean channel system from material collected in the last $124 \mathrm{yr}$ amounts to 431 (Montiel et al.). Based on this material the authors divided the Magellan region into an Atlantic and a Pacific subregion, both with $<10 \%$ endemics. The great majority of the Magellan polychaete species show wide distribution ranges and an obvious affinity both with Subantarctic and Antarctic areas. For the actual distribution pattern of polychaetes in the Cono Sur, the West Wind Drift plays an important role.

Harpacticoid copepods from sublittoral and bathyal depths in the "Cono Sur" still hold a great potential for future study. The large material encountered during two expeditions only allowed for species determination in six (out of 25) major taxa, which yielded 122 species, $>80 \%$ of which were new to science (George). The author emphasises the need for studies at species level, because species often show a much more restricted distribution than higher taxa. A second harpacticoid study was carried out in the Potter Cove (South Shetlands) (Veit-Köhler), with particular emphasis on the two species Pseudotachidius jubanyensis and Scottop- syllus praecipuus. Besides presenting numbers, the biovolume of the meiobenthic copepods was measured, the latter being related rather to total organic matter than to the $\mathrm{C}-\mathrm{N}$ ratio, chloroplastic equivalents, grain size or depth. However, neither of the two specifically studied species showed a relation to total organic matter.

A molecular survey of within-species genetic diversity on the Antarctic isopod Glyptonotus antarcticus, hitherto considered a single species, revealed high variability in the mitochondrial LSU (16S) gene (Held and Wägele). From a total of eleven unique mitochondrial haplotypes four groups were differentiated, which may represent cryptic species at the Antarctic Peninsula, in the Ross Sea and in the SE Weddell Sea (2).

The species inventories of two malacostracan crustacean taxa were updated in the south of the Magellan region. Shallow-water Asellota (isopods) from the Beagle Channel now amount to 23 species (Doti et al.). Faunistic affinities were high (65\%) with the Straits of Magellan; the entire Magellan region showed 30\% overlap with the Scotia Arc and $26 \%$ with the Antarctic Peninsula. Species richness and faunal affinities of gammaridean and corophiidean amphipods in southern Tierra del Fuego were studied by Chiesa et al. The authors identified 61mostly small-species, most of which belong to the Phoxocephalidae, Stenothoidae and Lysianassidae. Of these 39\% were endemic to the Magellan region.

Decapod distribution on the northern and southern branch of the Scotia Arc reveals a clear separation of Magellan and Antarctic elements respectively (Lovrich et $\boldsymbol{a l}$.), with an occurrence of both reptant and caridean species on the northern, and an impoverished caridean fauna on the southern branch. However, South Georgia holds a transitional position in combining these elements, which might be explained by occasional changes in the position of the Polar Front, as suggested in the review by Arntz et al. Differences were detected in the reproductive cycle of Notocrangon antarcticus and in the oocyte number of Munida subrugosa from different localities. A new index measuring the energy invested in reproduction revealed that this investment is species-specific, larger in caridean shrimps than in galatheid crabs, and independent of the sampling site. The decapod faunas from southern Chile and southern Argentina combined in the Magellanic Biogeographic Province are closely related, but show little association with the circumAntarctic decapod fauna (Boschi and Gavio), con- 
firming work published by e.g., Gorny (1999) and Thatje et al. (2005).

A Belgian interactive data base on Antarctic echinoids (south of the Polar Front) now comprises 81 species (David et al.), summarising taxonomic, ecological, morphological and distributional data and the sources of information. The CD-Rom is distributed with this volume.

A similar distribution as in the decapods (northern branch of the Scotia Arc: Magellan, southern branch: Antarctic) was found in 42 ascidian species collected during three Spanish expeditions (RamosEsplá et $\boldsymbol{a l}$.). South Georgia again holds a transitional position, with an intermediate ascidian fauna between the Antarctic Province and the Magellan region. Another ascidian study from the LAMPOS cruise, yielding 25 species or morphospecies, also states a transitional role of South Georgia, as it represents the northern limit for Antarctic species and the southern limit for Magellanic species (Tatián $\boldsymbol{e t}$ al.). The lower depth limits of the two studies $(600$ $\mathrm{m})$ were identical, but the latter upper range $(250 \mathrm{~m})$ was much deeper than the former $(10 \mathrm{~m})$, which may explain the different species numbers.

Mega- and macrobenthic associations were sampled in the south Chilean fjord system by Ríos $\boldsymbol{e t} \boldsymbol{a l}$. using an Agassiz trawl. A total of 131 species were collected, with echinoderms (47 spp.) and polychaetes (46 spp.) as dominant taxa. Marked differences were found between the impoverished benthic fauna in the fjords and channels off the South Patagonian Icefields, revealing strong glacier impact, and the richer fauna in the Straits of Magellan.

Progress in macrobenthic studies on the Antarctic and Magellan shelves and upper slopes since the first IBMANT Symposium is reported by Arntz et $\boldsymbol{a l}$., placing the emphasis on shipboard sampling. Considerable progress is visible in biodiversity and biogeography on the Magellan-Antarctic latitudinal gradient, the influence of disturbance on biodiversity, and the general role of evolutionary and ecological factors in shaping past and present-day environmental conditions, species composition and distribution, and ecosystem functioning. Benthic life strategies and physiological adaptations (see Pörtner et al.) have also received due attention. Methods have been improved substantially, and modern approaches play an increasing role. On the other hand, much remains to be done. Research in the Magellan region, which has not advanced with the pace experienced in the Antarctic, must be enhanced. The same is true for other undersampled areas, such as most of the East Antarctic, Bouvet Island or the Bellingshausen Sea, or the rare shallow sites in the Weddell Sea. Areas recently freed from ice shelves such as the Larsen ice shelf should be studied intensely. Much more interdisciplinary work is necessary to tackle the numerous open questions about the relations between environmental change and organismic evolution in the Subantarctic and Antarctic. Molecular methods need to be improved, and validation with the help of palaeontologists increased in order to reach more concise datings of evolutionary processes.

Based on comparisons of fish and invertebrate metabolism along latitudinal gradients in both hemispheres, Pörtner $\boldsymbol{e t}$ al. analyse characteristics of temperature dependent metabolic adaptation and their consequences for changes in energy budgets. Temperature sensitivity of growth is considered a key component for energy budgets. Apparently, natural selection helps individuals to reach high energy efficiency and maximized growth, but is constrained by limited energy availability and temperature. However, the assumption that levels of metabolic rates could be estimated just from mean temperatures is too simple, and there are distinct differences between the permanently low temperature ecosystems of the Antarctic as compared to the Subarctic and Arctic, where temperature variability is greater. This variability causes a rise in maintenance costs at the expense of growth but in favour of agility and foraging capacity, whereas savings in maintenance costs, setting free energy for growth, are maximised under the permanently low temperatures of the Antarctic. The authors emphasise that their energy budget hypothesis and the suggested trade-offs between life style, agility and growth performance explain most of the patterns observed in stenotherms and eurytherms on a latitudinal gradient.

Ultraviolet $\mathrm{B}$ radiation reaching the surface of the Southern Ocean has significantly increased due to the reduction of the stratospheric ozone. Based on the investigation of a phytoflagellate and a diatom, Hernando et al. conclude that the balance between damage and repair after UV radiation involves the combined action of several internal factors in the cell, suggesting that exposure to mild oxidative stress initiates adaptive responses that provide increased protection against more severe stress. In another study, Malanga et al. investigated the effect of air exposure and temperature fluctuations at different tidal levels on oxidative stress parameters in gills of Magellan and Antarctic limpets (Nacella 
spp.). In the Beagle Channel, N. magellanica lives in the intertidal and suffers high environmental variability, whereas $N$. deaurata is usually covered by shallow water and experiences comparatively constant conditions. The Antarctic N. concinna is found both at inter- and subtidal levels. Antarctic Peninsula specimens from the upper intertidal showed significantly increased activities of catalase and superoxide dismutase as compared to their relatives at lower levels. No pronounced difference in oxidative stress parameters or in oxygen uptake was detected between the two limpets from the Beagle Channel. The proposed mechanism that controls oxidative stress in the intertidal N. magellanica could, according to these authors, be the way in which the limpets control the content of catalytically active iron II (including reduction rates of iron III) in their tissues. The conclusion from the two contributions is that coping with a demanding environment requires complex metabolic adjustments to minimise intracellular damage.

Antarctic fish (Notothenioidei) deserve special attention because unlike most other fish taxa, this group adapted successfully to cold conditions. The reproductive development of notothenioid fish caught in the Scotia Arc during the LAMPOS cruise differed substantially among the different species. Fecundity in channichthyids was lower than in nototheniids. Spawning revealed the same characteristics as in the high Antarctic, with delayed maturity, moderate fecundity, a single spawning per year and prolonged gametogenesis (Vanella et al.). Vanella and Calvo studied the influence of temperature on the routine metabolic rate of Subantarctic teleosts and compared the results with the rates of species with different geographical distributions. In the 5 studied species and all tested temperatures, body mass and oxygen consumption showed a positive correlation. A massive drop in temperature caused a significant reduction in oxygen consumption. Pelagic species had a higher $\mathrm{O}_{2}$ consumption than sluggish demersal species. The authors conclude that similar to fish in the Antarctic proper, Subantarctic fish have not developed metabolic cold adaptation.

The axial muscle of Antarctic and some Subantarctic notothenioids contains exceptionally large muscle fibres and a low fibre number. Species from both regions showed no differences in the number and type composition of fibres, or in ATPase activity, fibre recruitment and swimming performance. However, fibre number and fibre diameter decrease in the more derived families, and the duration of the cell cycle showed cold compensation in the Antarctic Harpagifer species in comparison with its Subantarctic relative. Apparently, the diversification of Antarctic notothenioids was associated with a sizespecific reduction in fibre numbers and an increase in fibre diameter. This finding presents a great opportunity to study the temperature-related mechanisms of muscle growth in an evolutionary context (Fernández et al.).

Stalked crinoids were a conspicuous member of shallow marine benthic communities throughout much of the Palaeozoic, before they were outcompeted by the Mesozoic increase of durophagous predators (Aronson and Blake, 2001) and gave way to the mobile forms that prevail in the benthos today, with the exception of some refuges such as the deep sea. While post-late Cretaceous shallow water records of isocrinids are generally very rare, these forms were still abundant in Antarctic shallow water of the La Meseta Formation of Seymour Island in the late Eocene. Malumián and Olivero report the existence of another retrograde, dense Isselicrinus population, which successfully extended its distribution into the Leticia Formation of Tierra del Fuego. These occurrences in shallow water are in contrast with the depth distribution of stalked crinoids by that time, which was almost entirely a deep-water distribution.

The Late Glacial Maximum (LGM) in the Beagle area probably occurred ca. 20,000 yr BP (Rabassa et al., 1990). By 12,000 yr BP the ice seems to have disappeared from the coasts at Pto. Williams and Ushuaia, and large amounts of meltwater were filling the Beagle Channel (Heusser, 1989, 1998). Fossil marine records were first showing up around 8000 yr BP (Gordillo et al.). A diversification and expansion of molluscan assemblages occurred during the interval 5000-4000 yr BP, when an evolution towards modern conditions took place. Most species once established also survived later climatic deterioration. Both in Tierra del Fuego and in the Antarctic, molluscs are the most consistent fossil record, and all recovered taxa are extant species. Overlap of these palaeofaunas at the species level is low, as for recent species where it is $<10 \%$, but on genus and family level it is high. From the study of the fossil molluscan assemblages the authors conclude that most of the affinities and relationships between the Magellan and Antarctic molluscan faunas are a product of high-latitude radiation in the Quaternary rather than reflecting ancient connections during the Weddellian Province in the Palaeogene. 
The opening of the channel system of the "Cono Sur" after the LGM may have also created pathways for the exchange of Magellan polychaetes (Montiel et al.).

An outlook based on the presentations and discussions during the meeting is given by Thomson, who concludes that in the face of all the uncertainties about the late Cenozoic geological history, the doubts about major oceanographic processes and many unknown patterns in palaeontology and evolution, the time is opportune for a truly multidisciplinary international workshop. Both IBMANT and ANDEEP, under the roof of SCAR, might provide a framework for convoking the biological community, but efforts are also necessary from the other disciplines. After all, as Thomson says, the involved science communities have much to gain from each other.

\section{REFERENCES}

*Note: Authors without years mentioned in the text refer to this volume.

Arntz, W.E. and A. Clarke (eds.). - 2002. Ecological studies in the Antarctic sea ice zone. Springer, Berlin.

Arntz, W.E. and T. Brey (eds.). - 2003. The expedition ANTARKTIS XIX/5 (LAMPOS) of RV "Polarstern" in 2002. Ber. Polarforsch. Meeresforsch., 462.

Arntz, W.E. and M. Gorny (eds.). - 1996. Cruise report of the Joint Chilean-German-Italian Magellan "Victor Hensen" Campaign in 1994. Ber. Polarforsch., 190.

Arntz, W.E. and C. Ríos (eds.). - 1999. Antarctic-Magellan: Ecosystems that drifted apart. Sci Mar., 63(Suppl. 1).

Aronson, R.B. and D.B. Blake. - 2001. Global climate change and the origin of modern benthic communities in Antarctica. Am. Zool., 41: 27-39.

Barker, P.F. and J. Burrell. - 1977. The opening of Drake Passage. Marine Geology, 25: 15-34.

Barker, P.F. and E. Thomas. - 2004. Origin, signature and palaeoclimatic influence of the Antarctic Circumpolar Current. EarthScience Reviews, 66: 143-162.

Brandt, A. and B. Hilbig (eds.). - 2004. ANDEEP (Antarctic benthic deep-sea biodiversity: colonization history and recent community patterns) - a tribute to Howard L. Sanders. Deep-Sea Res. II, 51.

Clarke, A.C., W.E. Arntz and C. Smith (eds.). - Subm. Proceedings of EASIZ Final Symp., Korcula, Croatia. Deep-Sea Res. II

CONA (Comité Oceanográfico Nacional, Chile). - 1999a. Resultados crucero CIMAR-FIORDO, Resúmenes ampliados, 3: 1-144.

CONA (Comité Oceanográfico Nacional, Chile). - 1999b. Resultados crucero CIMAR-FIORDO, Resúmenes ampliados, 4: 1-76

Davison, W., C. Howard-Williams and P. Broady (eds.). - 2000. Antarctic ecosystems: Models for broader understanding. NZ Natural Sciences, Canterbury Univ., Christchurch.

Di Prisco, G., E. Pisano and A.C. Clarke (eds.). - 1998. Fishes of Antarctica. A biological overview. Springer, Milano.

Fernández, D.A., J. Calvo, C.E. Franklin and I.A. Johnston. - 2000. Muscle fibre types and size distribution in sub-Antarctic nototheniod fishes. J. Fish. Biol., 56: 1295-1311.

Gorny, M., 1999. - On the biogeography and ecology of the Southern Ocean decapod fauna. Sci Mar., 63(Suppl. 1): 367-382.

Heusser, C.J. - 1989. Late Quaternary vegetation and climate of southern Tierra del Fuego. Quaternary Res., 31: 396-406.

Heusser, C.J. - 1998. Deglacial paleoclimate of the American sector of the Southern Ocean: Late Glacial-Holocene records from the latitude of Canal Beagle $\left(55^{\circ} \mathrm{S}\right)$, Argentine Tierra del Fuego. Palaeogeogr. Palaeocl., 141: 277-301.

Hillis, D.M., B.K. Mable and C. Moritz. - 1996. Applications of molecular systematics: The state of the field and a look into the future. In: D.M. Hillis, C. Moritz, et al., Molecular systematics, pp. 515-543. Sunderland, Massachussetts, Sinauer Associates.

Huiskes, A.H.L., W.W.C. Gieskes, J. Rozema, R.M.L. Schorno, S.M. van der Vies and W.J. Wolff (eds.). - 2003. Antarctic biology in a global context. Backhuys Publ., Leiden.

Lovrich, G., S. Thatje, J.A. Calcagno, K. Anger and A. Kaffenberger. - 2003. Changes in biomass and chemical composition during lecithotrophic larval development of the southern king crab Lithodes santolla (Molina). J. exp. mar. Biol. Ecol., 288: 65-79.

Mackensen, A. - 2004. Changing Southern Ocean palaeocirculation and effects on global climate. Antarctic Sci., 16: 369-386.

Rabassa, J., D. Serrat, C. Marti and A. Coronato. - 1990. El Tardiglacial en el Canal Beagle, Tierra del Fuego, Argentina y Chile. Actas XI Congr. Geol. Arg., 1: 290-293. San Juan, Argentina (fide S. Gordillo).

Thatje, S. and V. Fuentes. - 2003. First record of anomuran and brachyuran larvae (Crustacea: Decapoda) from Antarctic waters. Polar Biol., 26: 279-282.

Thatje, S., K. Anger, J.A. Calcagno, G.A. Lovrich, H.O. Pörtner and W.E. Arntz. - 2005. Challenging the cold: crabs reconquer the Antarctic. Ecology, 86: 619-625.

Contributions to the volume "The Magellan-Antarctic connection: Links and frontiers at high southern latitudes" (in alphabetical order)

Arntz, W.E. - 2005. The Magellan-Antarctic connection: links and frontiers at southern high latitudes. Summary review. Sci. Mar., 69(Suppl. 2): 359-365.

Arntz, W.E., G. Lovrich and S. Thatje. - 2005. IBMANT II Symposium and Workshop. Foreword. Sci. Mar., 69(Suppl. 2): 3-5.

Arntz, W.E., S. Thatje, D. Gerdes, J.-M. Gili, J. Gutt, A. Montiel, C. Orejas and N. Teixidó. - 2005. The Antarctic-Magellan connection: macrobenthic studies on the shelf and upper slope, a progress report. (K) Sci. Mar., 69(Suppl. 2): 237-269.

Barnes, D.K.A. - 2005. Changing chain: past, present and future of the Scotia Arc's and Antarctica's shallow benthic communities. (K) Sci. Mar., 69(Suppl. 2): 65-89.

Berkman, P.A., R. Cattaneo-Vietti, M. Chiantore, C. HowardWilliams, V. Cummings and R. Kvitek. - 2005. Marine research in the Latitudinal Gradient Project along Victoria Land, Antarctica. (K) Sci. Mar., 69(Suppl. 2): 57-63.

Boltovskoy, D., N. Correa and A. Boltovskoy. - 2005. Diversity and endemism in cold waters of the South Atlantic: contrasting patterns in the plankton and the benthos. (K) Sci. Mar., 69(Suppl. 2): 17-26.

Boschi, E.E. and M.A. Gavio. - 2005. On the distribution of decapod crustaceans from the Magellanic Biogeographic Province and the Antarctic region. Sci. Mar., 69(Suppl. 2): 195-200.

Chiesa, I.L., G.M. Alonso and D.G. Zelaya. - 2005. Species richness and faunistic affinities of the Gammaridea and Corophiidea (Amphipoda) from shallow waters of southern Tierra del Fuego, Argentina: preliminary results. Sci. Mar., 69(Suppl. 2): 167-174.

David, B., T. Choné, A. Festeau, R. Mooi and C. De Ridder. - 2005. Biodiversity of Antarctic echinoids: a comprehensive and interactive data base. Sci. Mar., 69(Suppl. 2): 201-203.

Doti, B.L., D. Roccatagliata and D.G. Zelaya. - 2005. The shallowwater Asellota (Crustacea: Isopoda) from the Beagle Channel: preliminary taxonomic and zoogeographical results. Sci. Mar., 69(Suppl. 2): 159-166.

Fernández, D.A., J. Calvo and I.A. Johnston. - 2005. Muscle growth in Antarctic and Subantarctic notothenioid fishes. (K) Sci. Mar., 69(Suppl. 2): 325-336.

Fernández-Severini, M.D. and M.S. Hoffmeyer. - 2005. Mesozooplankton assemblages in two bays of the Beagle Channel (Argentina) during January, 2001. Sci. Mar., 69(Suppl. 2): 27-37.

George, K.H. - 2005. Sublittoral and bathyal Harpacticoida (Crustacea, Copepoda) of the Magellan region. Composition, distribution and species diversity of selected major taxa. Sci. Mar., 69(Suppl. 2): 147-158.

Glorioso, P.D., A.R. Piola and R.R. Leben. - 2005. Mesoscale eddies in the Subantarctic Front, southwest Atlantic. Sci. Mar., 69(Suppl. 2): 7-15. 
Gordillo, S., A.M.J. Coronato and J.O. Rabassa. - 2005. Quaternary molluscan faunas from the island of Tierra del Fuego after the Last Glacial Maximum. Sci. Mar., 69(Suppl. 2): 337-348.

Häussermann, V. and G. Försterra. - 2005. Distribution patterns of Chilean shallow-water sea anemones (Cnidaria: Anthozoa: Actiniaria, Corallimorpharia); with a discussion of the taxonomic and zoogeographic relationships between the actinofauna of the SE Pacific, SW Atlantic and the Antarctic. Sci. Mar., 69(Suppl. 2): 91-102.

Held, C. and J.-W. Wägele. - 2005. Cryptic speciation in the giant Antarctic isopod Glyptonotus antarcticus (Isopoda, Valvifera, Chaetiliidae). Sci. Mar., 69(Suppl. 2): 175-181.

Hernando, M., G. Malanga and G.A. Ferreyra. - 2005. Oxydative stress and antioxidant defences generated by solar UV in a Subantarctic marine phytoflagellate. Sci. Mar., 69(Suppl. 2): 287-295.

Lovrich, G.A., M.C. Romero, F. Tapella and S. Thatje. - 2005. Distribution, reproductive and energetic conditions of decapod crustaceans along the Scotia Arc (Southern Ocean). Sci. Mar. 69(Suppl. 2): 183-193.

Malanga, G., M.S. Estevez, J. Calvo, D. Abele and S. Puntarulo. 2005. Oxidative stress in gills of limpets from the Beagle Channel: comparison with limpets from the Antarctic. Sci. Mar., 69(Suppl. 2): 297-304.

Malumian, N. and E. Olivero. - 2005. Shallow-water late middle Eocene crinoids from Tierra del Fuego: a new southern record of a retrograde community structure. Sci. Mar., 69(Suppl. 2): 349-353.

Montiel, A., D. Gerdes and W.E. Arntz. - 2005. Distributional patterns of shallow-water polychaetes in the Magellan region: a zoogeographical and ecological synopsis. Sci. Mar., 69(Suppl. 2): 123-133

Moyano, H.I. - 2005. Scotia Arc bryozoans from the LAMPOS expedition: a narrow bridge between two different faunas. Sci.
Mar., 69(Suppl. 2): 103-112.

Pörtner, H.O., D. Storch and O. Heilmayer. - 2005. Constraints and trade-offs in climate dependent adaptation: energy budgets and growth in a latitudinal cline. (K) Sci. Mar., 69(Suppl. 2): 271-285.

Ramos-Esplá, A.A., J. Cárcel and M. Varela. - 2005. Zoogeographical relationships of the littoral ascidiofauna around the Antarctic Peninsula, in the Scotia Arc and in the Magellan region. Sci. Mar., 69(Suppl. 2): 215-223.

Ríos, C., E. Mutschke, A. Montiel, D. Gerdes and W.E. Arntz. 2005. Soft-bottom macrobenthic faunal associations in the southern Chilean glacial fjord complex. Sci. Mar., 69(Suppl. 2): 225-236.

Schnack-Schiel, S.B. and E. Isla. - 2005. The role of zooplankton in the pelagic-benthic coupling. (K) Sci. Mar., 69(Suppl. 2): 39-55.

Tatián, M., J. Antaclia and R. Sahade. - 2005. Ascidians (Tunicata, Ascidiacea): species distribution along the Scotia Arc. Sci. Mar., 69(Suppl. 2): 205-214.

Thomson, M.R.A. -2005 . Thoughts on controls on evolution and dispersal of benthos in the Magellan-Scotia Arc region: a workshop proposal. (K) Sci. Mar., 69(Suppl. 2): 355-358.

Vanella, F.A. and J. Calvo. - 2005. Influence of temperature, habitat and body mass on routine metabolic rates of Subantarctic teleosts. Sci. Mar., 69(Suppl. 2): 317-323.

Vanella, F.A., J. Calvo, E.R. Morriconi and D.R. Aureliano. - 2005 Somatic energy content and histological analysis of the gonads in Antarctic fish from the Scotia Arc. Sci. Mar., 69(Suppl. 2): 305-316.

Veit-Köhler, G. - 2005. Influence of biotic and abiotic sediment factors on abundance and biomass of harpacticoid copepods in a shallow Antarctic bay. Sci. Mar., 69(Suppl. 2): 135-145.

Zelaya, D.G. - 2005. The bivalves from the Scotia Arc islands: species richness and faunistic affinities. Sci. Mar., 69(Suppl. 2): 113-122. 
